\title{
EXPRESSION OF HUMAN LEUKOCYTE ANTIGEN-E AND NATURAL KILLER CELLS IN INTRA UTERINE FETAL DEATH
}

\author{
Sri Sulistyowati, Muhammad Anggit Nugroho, Supriyadi Hari Respati, Soetrisno \\ Department of Obstetrics and Gynecology, Faculty of Medicine, Sebelas Maret University, Dr. Moewardi Hospital, \\ Surakarta
}

\begin{abstract}
ABSTRAK
Intra Uterine Fetal Death (IUFD) merupakan salah satu penyumbang angka kematian bayi. Human Leukocyte Antigen-E (HLA-E) dan Natural Killer Cells (sel NK) diduga memegang peranan penting terhadap terjadinya IUFD yang berhubungan dengan maladaptasi imun. Penelitian ini bertujuan untuk mengetahui ekspresi HLA-E dan sel NK dalam trofoblas pada IUFD dan kehamilan normal. Penelitian menggunakan pendekatan cross sectional yang dilakukan di bagian Obstetri dan Ginekologi RSUD Dr. Moewardi Surakarta, RS Jejaring dan Laboratorium Patologi Anatomi, Fakultas Kedokteran, Universitas Sebelas Maret, Surakarta. Jumlah sampel yang diteliti adalah 32 subjek, terdiri dari 16 subjek hamil normal dan 16 subjek IUFD. Subjek yang memenuhi kriteria inklusi dan eksklusi diperiksa ekspresi HLA-E dan sel NK pada trofoblas dengan metode imunohistokimia dan dilakukan analisis statistik dengan uji t. Rerata ekspresi HLA-E di trofoblas pada kelompok IUFD 17.30 \pm 6.69 , kehamilan normal 57.06 \pm 32.04 , dengan nilai $p=0.00$ ( $p<0.05$ ). Rerata ekspresi sel NK di trofoblas pada kelompok IUFD 78.62 \pm 36.43 , kehamilan normal 19.87 \pm 6.43 , dengan nilai $p=0.00$ ( $p<0.05$ ). Sebagai simpulan, ekspresi HLA-E lebih rendah dan sel NK lebih tinggi pada IUFD bila dibandingkan dengan hamil normal. (FMI 2017;53:252-257)
\end{abstract}

Kata kunci: HLA-E; sel NK; Intra Uterine Fetal Death

\begin{abstract}
Intra Uterine Fetal Death (IUFD) is one contributor to infant mortality. Human Leukocyte Antigen-E (HLA-E) and Natural Killer Cells (NK cells) are believed to play an important role towards IUFD associated with immune maladaptation. This study aimed to determine the expression of HLA-E and NK cells on trophoblast on IUFD and normal pregnancy. The study used cross sectional approach undertaken at Department of Obstetrics and Gynecology, Dr. Moewardi Hospital, Surakarta, networking hospitals, and Anatomic Pathology Laboratory of Faculty of Medicine, Sebelas Maret University. The number of samples were 32 subjects consisting of 16 subjects with normal pregnancy and 16 subjects with IUFD. The expression of HLA-E and NK cells on trophoblast of subjects who met the inclusion and exclusion criteria were examined using immunohistochemistry method and t-test statistical analysis. The mean value of HLA-E expression in the trophoblast of IUFD group was 17.30 \pm 6.69 , in normal pregnancy was $57.06 \pm 32.04$, with $p=0.00$ ( $p<0.05$ ). The mean value of $N K$ cell expression in trophoblast in IUFD group was 78.62 \pm 36.43 , in normal pregnancy was $19.87 \pm 6.43$, with $p=0.00$ ( $p<0.05$ ). This study concluded that the expression of HLA-E was lower and NK cells wass higher in IUFD compared to those in normal pregnancy. (FMI 2017;53:252-257)
\end{abstract}

Keywords: HLA-E; NK cells; Intra Uterine Fetal Death

Correspondence: Sri Sulistyowati, Department of Obstetrics and Gynecology, Dr. Moewardi Hospital, Surakarta, Jl. Kol. Sutarto 132 Surakarta, Indonesia. Telp/Fax: 0271 665145. Email: elis_spog@yahoo.co.id

\section{INTRODUCTION}

Intra Uterine Fetal Death (IUFD) is one contributor to infant mortality where infant mortality is used as one of the indicators to assess the welfare of a country (Gerungan et al 2016). IUFD is death of fetus in the uterus that occurs in gestational age $>20$ weeks or fetal weight $>350$ grams (Mattingly et al 2016). Another IUFD definition is fetal death in the uterus before delivery at $>24$ gestational weeks or fetal weight >500 grams (AlKadri \& Tamim 2012).

IUFD frequency in the United States in 2006 was almost as same as in 2002 which was 6.05/1000 live births and 6.4/1000 live births respectively. Throughout the world, IUFD frequency varies depending on the definition used (Silver 2007, Mattingly et al 2016). In Indonesia, IUFD incidence rate is still high compared to countries in Southeast Asia. In North Sulawesi in 2013, IUFD incidences were 293 cases from 331 neonatal deaths (Gerungan et al 2016). At Arifin Achmad Hospital in Pekanbaru, Riau Province, IUFD incidences in 2012 were 27 cases (10\%) from 2908 deliveries (Yuristin 2014).

The causes of IUFD in general are in mother's pathology (preeclampsia/eclampsia, anemia), in fetus (oligohydramnios, congenital abnormalities, umbilical cord 
abnormalities) and in placenta (placenta solution, placenta previa) (Patel et al 2014). One of the success of pregnancy process is determined by semi-allogeneic fetus which has the ability to avoid maternal immune system. Avoiding mechanism used by the embryo is not yet certainly known. Lately, Human Leukocyte Antigen (HLA) molecule including HLA-E was studied to determine the mechanism of maternal immune tolerance to the fetus (Hviid 2006).

Fetus, which is semi-allogeneic to the maternal immune system, is at high risk of being recognized as strange matter and removed, but in reality, this does not occur in a normal pregnancy. Cytotrophoblast which invades the maternal expresses HLA-E. HLA-E molecule has the ability to inhibit cytolytic response from cytotoxic $\mathrm{T}$ lymphocytes and NK cell activity via CD94/NKG2A receptor contained in endometrium (Tripathi et al 2007).

Today, many studies develop about the causes of early pregnancy failure including IUFD viewed from immune system disorders, especially in the process of embryo implantation. Successful implantation in humans depends on immune recognition system on an embryo from an early age, and maternal immune responses against the embryo (Flenady et al 2011).

HLA-E is a non-classical HLA class I which plays an important role to regulate cytokine secretion as trophoblast invasion controller and immune tolerance regulator locally in the placenta. HLA-E is dominantly expressed in extra villous trophoblast in the placenta and in the formation of hematopoietic system derived from extraembryonic yolk sac. HLA-E can protect trophoblast from maternal-fetal immune intolerance and allow the trophoblast cells to invade the uterus. HLA-E plays an important role in immune tolerance during pregnancy (Fotoohi et al 2016).

In humans, a defect in the liaison between the fetus and the mother, in this case is the trophoblast, is associated with various complications of pregnancy, such as preeclampsia, intrauterine growth, and failure of conception results (blighted ovum, recurrent miscarriage, and Intra Uterine Fetal Death) (Sulistyowati et al 2010).

Adequate HLA-E expression in the trophoblast is needed, so trophoblast will invade decidua and maternal vascular system, so that an increase of uterine perfusion is needed during pregnancy. However, if HLA-E reduces or not expressed, the ability of trophoblast cells will decrease and be prevented to invade uterus because it is considered as a non-self which has properties as antigens that trigger antibody formation in the mother. These antibodies bind antigens, and immunological reaction occurs that stimulates proinflammatory cyto- kine activation and activates $\mathrm{T}$ cells and natural killer cells that will attack trophoblast cells itself that results in fetal death (Mallia et al 2012).

NK cells of lymphocyte types play a role in the immune system as a first line of defense and has very important functions in reproduction immunology. NK cells are large granular lymphocytes (LGL) and are highly found in the uterus of pregnant women. Knowledge on the function of NK cells in the uterus is still limited. A huge number of NK cells at the beginning of pregnancy shows that these cells have an important role in pregnancy such as a defense against infection and also in the regulation of the maternal immune system that can affect implantation and placentation (Rodrigues et al 2013).

Natural Killer cells have an important role in pregnancy process. NK cells, through CD94/NKG2A receptors, can invade target cells. Uterine NK cells, that can be activated via CD94/NKG2A receptors that can bind HLA-E, have been shown to be associated with immunological processes in IUFD (Mallia et al 2012, Fukui et al 2012). This study aimed to determine the expression of HLA-E and NK cells in trophoblast IUFD that was expected to be a predictor, so that IUFD events may be lowered.

\section{MATERIALS AND METHODS}

This was observational analytic study with crosssectional approach. This study was conducted at the Department of Obstetrics and Gynecology, Dr. Moewardi Hospital, Surakarta and the networking hospitals. The examination of HLA-E and NK cell expression using immunohistochemistry method was performed at the Laboratory of Pathology, Faculty of Medicine, Sebelas Maret University, Surakarta.

This study was conducted in pregnant women with IUFD and normal pregnant women to analyze the expression of HLA-E in trophoblast and NK cells in decidua. The sample size was determined based on Murti's formula in 2010. Each group consisted of 16 persons. The inclusion criteria were mothers aged 20-35 years old, 20-40 weeks of gestational age in pregnancy with IUFD cases, and 37-40 weeks of gestational age in normal pregnancy, single fetus, still alive, and have willingness to participate in the study. The exclusion criteria were mothers with diabetes mellitus, kidney disease, heart disease, liver disease, chronic hypertension, infectious diseases and smoking, and fetuses with major congenital abnormalities. Both groups underwent examination on the expression of HLA-E and NK cells in extravillous trophoblast in which HLA-E were 
expressed and NK cells decidua were accumulating in the surrounding area.

The expressions of HLA-E and NK cells were shown with a bluish tint for weak positive, golden yellow for moderate positive, and brown for strong positive on the trophoblast. Observations were made as much as 9 visual fields using light microscope. Trophoblast cell number was calculated based on the expression intensity, and then the percentage was made from the whole number of cells. The percentage obtained was converted into numbers and calculated according to the histological score formula. Scoring of HLA-E and NK cell image was conveyed as Histology Score (HS) that was done based on the formula: $\mathrm{HS}=(\mathrm{PK} \times \mathrm{IK})+(\mathrm{PS} \times \mathrm{IS})$ $+(\mathrm{PL} x \mathrm{IL})+(\mathrm{PN} \times \mathrm{IN})$, in which $\mathrm{P}=$ Percentage, $\mathrm{K}=$ Strong, $\mathrm{N}=$ Negative, $\mathrm{I}=$ Intensity, $\mathrm{L}=$ Weak, and $\mathrm{S}=$ Medium. Histology scores of HLA-E and NK cells are as follows: the percentage/percentage of cell number: 0$25 \%=$ negative $; 26-50 \%=$ weak positive $; 51-75 \%=$ moderate positive; $76-100 \%=$ strong positive. Histology scores of HLA-E and NK cells are as follows: qualitative meaning: 0.00 to $3.75=$ negative; 3.76 to 7.50 = weak positive; 7.51 to $11.25=$ medium positive; 11.26 to $15,00=$ strong positive (Sargent et al 2007).

The data were analyzed using t-test. Reagents used for the expression of HLA-E was HLA-E antibodies from Santacruz Biotechnology and reagents used for the expression of NK cell was rabbit polyclonal antibody Anti KIR2DL1 bs-2419R BIOSs, Inc., and KIR was used to see the expression of NK cell receptors. Observations on intensity of the color was done by using Olympus CX-21 series light microscope at 400 times magnification on 9 visual fields. The number of HLA-E and NK cells in the trophoblast was calculated based on the intensity of the reddish-brown color, and the percentage was calculated. The higher the histological score, the stronger the expression.

\section{Ethical clearance}

The Ethical Clearance was obtained from the Health Research Ethics Commission of Dr. Moewardi Hospital/Faculty of Medicine, Sebelas Maret University, Surakarta, Number: 443/V/HREC/2016 dated May 23, 2016.

\section{RESULTS}

Table 1 shows that the mean value of mothers' age is $28.6 \pm 5.07$ years old, gestational age is $36.71 \pm 3.7$ weeks, systolic blood pressure is $122.53 \pm 33.56 \mathrm{mmHg}$ and diastolic blood pressure is $80.78 \pm 18.88 \mathrm{mmHg}$. The level of hemoglobin was $12.40 \pm 2.04 \mathrm{gr} / \mathrm{dl}$, urea was $15.28 \pm 4.80 \mathrm{mg} / \mathrm{dl}$, creatinine was $0.72 \pm 0.20 \mathrm{mg} / \mathrm{dl}$, AST was 58.06 $\pm 109.04 \mathrm{U} / \mathrm{I}$ and SGPT was $29.46 \pm 48.84 \mathrm{U} / \mathrm{I}$, random blood glucose was $92.81 \pm 10.89 \mathrm{mg} / \mathrm{dl}$, HLA-E expression was $37.18 \pm 30.43 \%$ cells/field of view and NK cells was $49.24 \pm 39.40 \%$ cells/field of view.

Table 1. Characteristics of the study subjects

\begin{tabular}{lccccc}
\hline \multicolumn{1}{c}{ Variable } & N & Min & Max & Mean & SD \\
\hline Mother's age (years) & 32 & 19.00 & 35.00 & 28.06 & 5.07 \\
Gestational age (weeks) & 32 & 26.00 & 40.00 & 36.71 & 3.70 \\
Systolic blood pressure (mmHg) & 32 & 11.00 & 190.00 & 122.53 & 33.56 \\
Diastolic blood pressure (mmHg) & 32 & 60.00 & 130.00 & 80.78 & 18.88 \\
Hemoglobin (gr/dl) & 32 & 6.00 & 15.70 & 12.40 & 2.04 \\
Urea (mg/dl) & 32 & 7.00 & 23.00 & 15.28 & 4.80 \\
Creatinine (mg/dl) & 32 & 0.40 & 1.20 & 0.72 & 0.20 \\
SGOT (U/I) & 32 & 14.00 & 587.00 & 58.06 & 109.04 \\
SGPT (U/I) & 32 & 6.00 & 202.00 & 29.46 & 48.84 \\
Random Blood Sugar (mg/dl) & 32 & 67.00 & 110.00 & 92.81 & 10.89 \\
HLA-E (\% cells/field of view) & 32 & 0.22 & 146.46 & 37.18 & 30.43 \\
NK cells (\% cells/field of view) & 32 & 9.98 & 161.71 & 49.24 & 39.40 \\
\hline
\end{tabular}

Table 2. Mean expression of HLA-E and NK cells in trophoblast of IUFD and normal pregnancy

\begin{tabular}{lccc}
\hline \multicolumn{1}{c}{ Variables } & $\begin{array}{c}\text { IUFD } \\
(\mathrm{N}=16)\end{array}$ & $\begin{array}{c}\text { Normal } \\
\text { Pregnancy } \\
(\mathrm{N}=16)\end{array}$ & $\mathrm{p}$ \\
\hline $\begin{array}{l}\text { HLA-E (\% cells / field of view) } \\
\text { NK cells }(\% \text { cells / field of } \\
\text { view) }\end{array}$ & $17.30 \pm 6.69$ & $57.06 \pm 32.04$ & $0.00^{*}$ \\
\hline Note: $*$ Significant if $\mathrm{p}<0.05$ & $78.62 \pm 36.43$ & $19.87 \pm 6.43$ & $0.00^{*}$ \\
\hline
\end{tabular}


Table 2 presents that the mean value of HLA-E expression in the trophoblast of IUFD group is lower $(17.30 \pm 6.69)$ compared to normal pregnancy group $(57.06 \pm 32.04)$, with $\mathrm{p}$ value $=0.00(\mathrm{p}<0.05)$. The mean expression of NK cells in trophoblast group IUFD was higher (78.62 \pm 36.43$)$ compared to normal pregnancy group $(19.87 \pm 6: 43)$ with $p$ value $=0.00(\mathrm{p}<0.05)$.

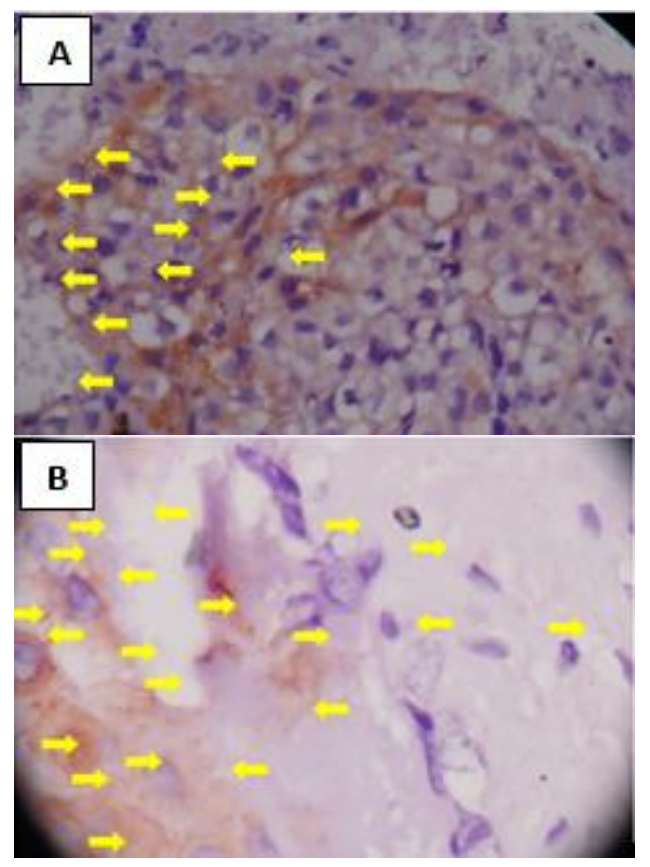

Fig. 1. The expression of HLA-E in trophoblast of normal pregnancy and IUFD: A. HLA-E expression in trophoblast of IUFD pregnancy; B. HLA-E expression in trophoblast of normal pregnancy.

Fig. 1 shows the expression of HLA-E on trophoblast of IUFD and normal pregnancy using immunohistochemical method. By using Olympus CX21 series microscope with a magnification of 400 times, the expression of HLA-E was shown by reddish brown color on the core extending into the cytoplasm for strong positive, dark brown showed moderate positive, light brown showed weak positive, and blue showed negative. The expression of HLA-E on IUFD appeared weaker (Fig. 1B) compared to the expression in normal pregnancy (Fig. 1A).

Fig. 2 shows the expression of NK cells on trophoblast of IUFD and normal pregnancy using immunohistochemical method. By using Olympus CX21 series microscope with a magnification of 400 times, NK cell expression was shown with reddish brown color on the core extending into the cytoplasm for strong positive, dark brown showed moderate positive, light brown showed weak positive:, and blue showed negative. Expression of NK cells in IUFD looked stronger/higher (Fig. 2A) when compared to expression in normal pregnancy (Fig. 2B).

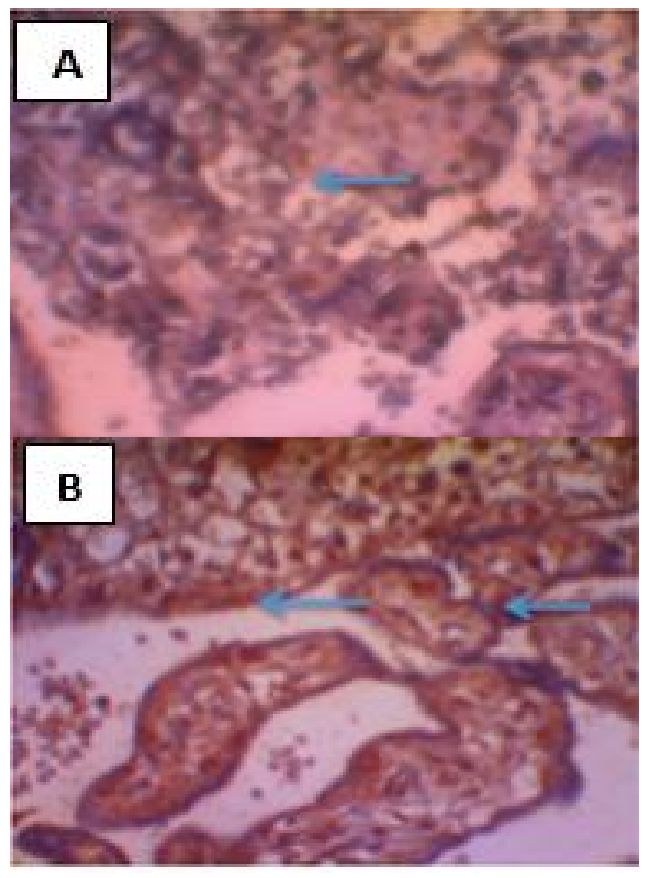

Fig. 2. Expression of NK cells on trophoblast of IUFD and normal pregnancy: A. NK cells expression in trophoblast of pregnancy with IUFD, B. NK cells expression in trophoblast of normal pregnancy

\section{DISCUSSION}

Pregnancy is a unique situation where maternal fetal tolerance is very important to ensure the development of placenta and fetus. Inadequate placentation will cause unwanted effects on the mother or the fetus, including preeclampsia, fetal growth retardation, and IUFD (Haumonte et al 2014). During pregnancy, maternal immune system always performs direct contact with cells and tissues of semi-allogeneic fetus. Therefore, there must be various mechanisms to modulate and reduce maternal immune system response toward the stimulus. HLA-E inhibits cell lysis induced by $\mathrm{T}$ cells and NK cells through direct interaction with CD94/NKG2A receptor inhibitors, so trophoblast cells do not experience lysis. Strong HLA-E expression in the trophoblast cells simultaneously with HLA-G expression in fetomaternal interface will decrease NK cells activation that will succeed the pregnancy (Tripathi et al 2007). HLA-E is expressed in cytotrophoblast associated with maternal tissue (decidua cells), and its expression increases during pregnancy (Hunt \& Langat 2006). 
It is hypothesized that immunologically HLA-E is permissive on antigen incompatibility between mother and fetus.

In this study, the mean expression of HLA-E in trophoblast on IUFD was lower compared to normal pregnancies. The mean expression of NK cells in the trophoblast on IUFD was higher compared to normal pregnancy. The results of this study were in line with the research conducted by Fotoohi in 2016 that obtained lower HLA-E in recurrent spontaneous abortion including IUFD than normal pregnancy because HLA-E is an antigen that interact with NKG2A which is a receptor inhibitor of $\mathrm{NK}$ cells that help the fetus to face the response of maternal immunity, so when HLA-E deficiency occurs, the fetus is more vulnerable to NK cells attack that will cause IUFD (Fotoohi et al 2016). Increased HLA-E activity will attain a pregnancy, since HLA-E is believed to protect the fetus from maternal immune attack through the interaction of CD94/NKG2A NK cells (Mallia et al 2012, Tripathi et al 2007, Hviid 2006). In contrast to this study, Matter \& Sharif in 2013 found that HLA-E on recurrent spontaneous abortion including IUFD is not significantly different compared to normal pregnancy. This might be because of inadequate number of samples.

HLA-E significantly increased in placental tissue during first trimester pregnancy especially on extravilli membrane, while it occurred on intravilli membrane in final trimester pregnancy. The type of expression was in accordance with the theory that HLA-E likely plays a role in fetal protection. It may be related to the structure of non-immune and immune function at the site of fetomaternal relationship. The recent evidence indicates the immune function in which HLA-E protects the fetus from maternal uterine $\mathrm{NK}$ cells, which are huge in numbers in the cells invading trophoblast. Therefore, HLA-E is an important factor to prevent the incidence of pregnancy complications such as recurrent miscarriage, IUFD, preeclampsia, and fetal growth retardation (Mallia et al 2012).

Similar to this study, Haumonte et al in 2014 also obtained higher level of NK cells in IUFD cases. Maternal immune maladaptation will generate increased Th1 that will increase NK cell activation and secrete cytokines that are destructive to trophoblast, including TNF-a, IFN-?, TGF- 3 , and IL-2. This state will cause IUFD (Morandi et al 2014). CD56bright NK cells greatly increased in recurrent spontaneous abortion and IUFD. This is because the NK cells to produce Th1 cells that will cause undesirable pregnancy outcome like IUFD (Sharma 2014). A retrospective study by Fukui et al in 2012 also said that NKGA level on NK cells was found increasing in couples with recurrent spontaneous abortion (RSA) and fetal death (Fukui et al 2012).

\section{CONCLUSION}

The expression of HLA-E is lower and NK cells is higher in IUFD compared to those in normal pregnancy.

\section{ACKNOWLEDGMENT}

We would like to thank the Director of Dr. Moewardi Hospital, dr. Endang Agustinar, M.Kes, and the networking hospital for allowing us to conduct research at the hospitals, and the staffs of Department of Anatomic Pathology, Faculty of Medicine, UNS, for their assistance in immunohistochemical examination.

\section{REFERENCES}

Al-Kadri HM, Tamim HM (2012). Factors contributing to intra-uterine fetal death. Arch Gynecol Obstet 286, 1109-16

Flenady V, Koopmans L, Middleton P, Froen JF, Smith GC, Gibbons K et al (2011). Major risk factors for stillbirth in high-income countries: a systematic review and meta-analysis. The Lancet 377, 1331-1340

Fotoohi M, Ghasemi N, Mirghanizadeh SA, Vakili M, Samadi M (2016). Association between HLA-E gene polymorphism and unexplained recurrent spontaneous abortion (RSA) in Iranian women. Int $\mathrm{J}$ Reprod Biomed (Yazd) 14, $477-482$

Fukui A, Yokota M, Funamizu A, Nakamua R, Fukuhara R, Yamada K et al (2012). Changes of NK cell in preeclampsia. Am J Reprod Immunol 67, 27886

Gerungan EN, Pascoal M, Lontaan A (2016). Faktorfaktor yang berhubungan dengan kejadian intra uterine fetal death (IUFD). Jurnal Ilmiah Bidan 4, 9 - 14

Haumonte JB, Caillat-Zucman S, Bretelle F, Lambert M, Lyonnet L, Levy-Mozziconacci A, et al (2014). Enhanced prevalence of plasmatic soluble MHC class i chain-related molecule in vascular pregnancy diseases. BioMed Research International 2014, 1 - 11

Hunt JS, Langat DL (2009). HLA-G: A human pregnancy-related immunomodulator. Curr Opin Pharmacol, 9, 462-469

Hviid TVF (2006). HLA-G in human reproduction: aspects of genetics, function and pregnancy complications. Human Reproduction Update 12, 209-232

Mallia JV, Das DK, Maitra A (2012). Role of HLA in pregnancy. Int J Hum Genet 12(1), $33-6$

Matter TF, Sharif FA (2013). HLA-G and HLA-E Gene polymorphisms in idiopathic recurrent spontaneous 
abortion women in Gaza strip-Palestine. Int J Reprod Contracept Obstet Gynecol 2,3,277-283

Mattingly PJ, Joy S, Talavera F (2016). Evaluation of fetal death. Medscape. http://emedicine.medscape.com /article/259165-overview

Morandi F, Airoldi I, Pistoia V (2014). IL-27 Driven Upregulation of Surface HLA-E Expression on Monocytes Inhibits IFN- Release by Autologous NK Cells. Journal of Immunology Research 2014. http://dx.doi.org/10.1155/2014/938561

Murti B (2010). Desain dan Ukuran Sampel Untuk Penelitian kuantitatif dan Kualitatif di Bidang Kesehatan. Yogyakarta: universitas gajah Mada.

Patel S, Thaker R, Shah P, Majumder S (2014). Study of causes and complications of intra uterine fetal death (IUFD). Int J Reprod Contracept Obstet Gynecol 3(4), 931-935

Rodrigues MN, Favaron PO, Dombrowski JG, Souza RM, Miglino MA (2013). Role of natural killer (NK) cells during pregnancy: A review. Open Journal of Animal Sciences 3, 138-144
Sargent IL, Borzychowski AM, Redman CWG (2007). NK Cell and pre-eclampsia. J Reprod Immunol 76(12), $40-4$

Sharma $S$ (2014). Natural killer cells and regulatory $T$ cells in early pregnancy loss. Int $\mathrm{J}$ Dev Biol 58, 0 , 219-229.

Silver RM (2007). Fetal death. Obstet Gynecol 109,153-67

Sulistyowati S, Abadi A, Hood J, Soetjipto (2010). The influence of low HLA-G protein expression on Hsp-70 and VCAM-1 profile in preeclampsia. Indones $\mathrm{J}$ Obstet Gynecol 34(4), 185 - 190.

Tripathi P, Naik S, Agrawal S (2007). Role of HLA-G, HLA-E and KIR2DL4 in Pregnancy. Int J Hum Genet 7, 219-233

Yuristin D (2014). Hubungan anemia dengan kejadian Intra Uterine Fetal Death (IUFD) di RSUD Arifin Achmad Pekanbaru Propinsi Riau tahun 2011 - 2012. ISSN 97724DB915DD4, Vol 1 